\title{
APOPTOSIS INDUCTION IN HUMAN LEUKEMIA CELLS BY NOVEL 2-AMINO-5-BENZYLTHIAZOLE DERIVATIVES
}

\author{
N. S. FINIUK $K^{1,2}$, I. I. IVASECHKO ${ }^{1}$, O. YU. KLYUCHIVSKA ${ }^{1}$, \\ Yu. V. OSTAPIUK ${ }^{3}$, V. P. HRENIUKH ${ }^{2}$, Ya. R. SHALAI', \\ V. S. MATIYCHUK ${ }^{3}$, M. D. OBUSHAK ${ }^{3}$, \\ A. M. BABSKY², R. S. STOIKA ${ }^{1 \bowtie}$
}

\begin{abstract}
${ }^{1}$ Institute of Cell Biology, National Academy of Sciences of Ukraine, Lviv; ${ }^{2}$ Ivan Franko National University of Lviv, Biology Faculty, Lviv, Ukraine; ${ }^{3}$ Ivan Franko National University of Lviv, Chemistry Faculty, Lviv, Ukraine; e-mail: stoika@cellbiol.lviv.ua
\end{abstract}

Received: 21 December 2018; Accepted: 20 March 2019

\begin{abstract}
Derivatives of 2-amino-5-benzylthiazole are heterocyclic pharmacophores that exhibit different pharmacological activities including anticancer action. The mechanisms of such action of these compounds are not clear. The aim of the present study was to investigate apoptosis induction, particularly DNA damage in human leukemia cells, by the novel synthesized thiazole derivatives - 2,8-dimethyl-7-(3-trifluoromethyl-benzyl)pyrazolo[4,3-e]thiazolo[3,2-a]pyrimidin-4(2H)-one (compound 1) and 7-benzyl-8-methyl2-propylpyrazolo[4,3-e]thiazolo[3,2-a]pyrimidin-4(2H)-one (compound 2). Western-blot analysis, DNA comet assay in alkaline conditions, diphenylamine DNA fragmentation assay, agarose gel retardation, and methyl green DNA intercalation assays were used to study the effects of the studied compounds in human leukemia cells. These compounds induced PARP1 and caspase 3 cleavage in the leukemia cells, also increased the level of pro-apoptotic Bim protein and the mitochondrion-specific EndoG nuclease, and decreased the level of the anti-apoptotic Bcl-2 protein. They caused DNA single-strand breaks and DNA fragmentation in the leukemia cells without direct DNA binding or DNA intercalation. Thus, novel 2-amino-5-benzylthiazole derivatives may be promising agents for apoptosis induction in the targeted human leukemia cells.
\end{abstract}

Ke y w o r d s: 2-amino-5-benzylthiazole, Doxorubicin, apoptosis, DNA damage, leukemia.

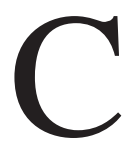
ancer is one of the major worldwide health problems. Standard chemotherapeutic strategies used for treatment of cancer patients do not have specific action and cause general toxicity. Another drawback of cancer chemotherapy is development of multidrug resistance in the treated patients [1].

As potential anticancer agents, heterocyclic compounds have been synthesized and their activity has been investigated [1-5]. Antifungal, antimicrobial, anticonvulsant, and antiproliferative activities have been also reported for thiazoles [1, 3, 4]. Li et al. demonstrated that thiazolo[5,4-d]pyrimidine (5-(benzylthio)-7-morpholino-N-phenylthiazolo[5,4d]pyrimidin-2-amine) possesses growth inhibition effects towards human gastric cancer MGC803, gas- tric carcinoma HGC27, and lung cancer H1650 cells [4]. The pyridyl-thiazoles possess antiproliferative activity for human acute $\mathrm{T}$ lymphocyte leukemia Jurkat and colorectal HT-29 cells [5].

Introduction of fluorine-containing groups into the structure of the molecules of bioactive agents was shown to increase plasma membrane permeability, metabolic stability of targeted cells, efficacy and selectivity of action [1]. The fluorinated pyrazolo[3,4-d]pyrimidine derivatives possess antitumor activity towards human leukemia HL-60 cells. Besides, compounds with the $\mathrm{H}$ atom at position 1 of the pyrazole ring were more active than those with a phenyl group [6]. The thiazole derivatives with a 4-(trifluoromethyl)-benzylidene possess antiproliferative activity towards human bronchial

(C) 2019 Finiuk N. S. et al. This is an open-access article distributed under the terms of the Creative Commons Attribution License, which permits unrestricted use, distribution, and reproduction in any medium, provided the original author and source are credited. 
epithelial NCI-H292, carcinoma HEp-2, and leukemia (K562, HL-60) cells [1].

In a previous study, we have shown that 2,8-dimethyl-7-(3-trifluoromethyl-benzyl)pyrazolo[4,3-e] thiazolo[3,2-a]pyrimidin-4(2H)-one (compound 2 in [7], in this manuscript - compound 1) and 7-benzyl-8-methyl-2-propylpyrazolo[4,3-e]thiazolo[3,2-a] pyrimidin-4(2H)-one (compound 7 in [7], in this manuscript - compound 2) possess cytotoxic action towards human leukemia cells (K562, HL-60 and the multidrug resistant subline of human myeloid leukemia HL-60/ADR cells) [7]. At the same time, these compounds possess low cytotoxicity towards non-tumor human embryonic kidney HEK293 cells, human keratinocytes of the HaCaT line, and murine macrophages of the J774.2 line, and were less toxic than doxorubicin (Dox) [7]. The mechanism underlying such anti-proliferative activity of those 2-amino-5-benzylthiazole derivatives was not studied. Here we investigated the pro-apoptotic action, specifically the DNA damaging effects, of compounds $\mathbf{1}$ and $\mathbf{2}$ in human leukemia cells.

\section{Materials and Methods}

Studied compounds. The 2,8-dimethyl-7-(3trifluoromethylbenzyl)pyrazolo[4,3-e]thiazolo[3,2a]pyrimidin-4(2H)-one (compound $\mathbf{1}$ ) and 7-benzyl8-methyl-2-propylpyrazolo[4,3-e]thiazolo[3,2-a] pyrimidin-4(2H)-one (compound 2) were synthesized at the Organic Chemistry Department of Ivan Franko National University of Lviv, Ukraine and dissolved in dimethyl sulfoxide (DMSO, SigmaAldrich, St. Louis, Missouri, USA). Then, working solutions of these compounds were prepared using culture medium [7]. Dox was purchased from Teva (Haarlem, the Netherlands) and used as a positive control.

Cell culture. Human myeloid leukemia HL-60 and K562 cells were obtained from a Collection of the Institute for Cancer Research at Vienna Medical University (Vienna, Austria). Cells were cultured under standard conditions in the RPMI-1640 medium (APP, Vienna, Austria) supplemented with 10\% fetal bovine serum (FBS, APP, Vienna, Austria).

Western-blot analysis. The leukemia HL-60 cells were treated with compounds $\mathbf{1}, \mathbf{2}$, and Dox (all at $0.09 \mu \mathrm{M}$ ) and K562 cells were treated with compounds 1, 2 (both at $3 \mu \mathrm{M}$ ), and Dox $(10 \mu \mathrm{M})$ for $48 \mathrm{~h}$. Concentrations of the compounds were chosen based on their IC $_{50}$ in HL-60 and K562 cells. The $\mathrm{IC}_{50}$ of compounds $\mathbf{1}$ and $\mathbf{2}$ towards HL-60 cells were 0.090 and $0.096 \mu \mathrm{M}$, respectively, and for $\mathrm{K} 562$ cells, the $\mathrm{IC}_{50}$ were $3.0 \mu \mathrm{M}$ and $3.1 \mu \mathrm{M}$, respectively. The $\mathrm{IC}_{50}$ of Dox towards HL-60 cells was $0.090 \mu \mathrm{M}$ and was $10.2 \mu \mathrm{M}$ for K562 cells [7]. Cellular proteins were extracted with a lysis buffer (20 mM Tris-HCl, pH 8.0, 1\% Triton-X100, 150 mM $\mathrm{NaCl}, 50 \mathrm{mM} \mathrm{NaF}, 0.1 \%$ SDS) that contained $1 \mathrm{mM}$ phenylmethanesulfonyl fluoride (PMSF) and $10 \mu \mathrm{g} /$ $\mathrm{ml}$ of protease inhibitors cocktail "Complete" (Basel, Roche, Switzerland). Proteins (30 $\mu \mathrm{g} / \mathrm{lane}$ ) were separated by SDS/PAGE gel-electrophoresis and transferred onto a polyvinylidene difluoride (PVDF) membrane [8]. The primary antibodies used were against Bim, cleaved Caspase 3 (Asp175), cleaved poly (ADP-ribose) polymerase 1 (PARP1) (Asp214), EndoG, phospho-extracellular signal-regulated kinase (ERK) 1/2 (Thr 202/Tyr 204) (Cell Signaling Technology, New England Biolabs GmbH, Vienna, Austria), Bcl-2 (Santa Cruz Biotechnology, Inc., Dallas, Texas, USA), and beta-actin monoclonal mouse AC-15 (Sigma-Aldrich, St. Louis, Missouri, USA). Secondary peroxidase-conjugated antibodies (Cell Signaling Technology, New England Biolabs GmbH, Vienna, Austria) were applied at a working dilution of 1:5,000. The enhanced chemiluminescence (ECL) detection reagents (Sigma-Aldrich, St. Louis, Missouri, USA) were used for protein visualization. Densitometric analysis of the protein level was performed using open source ImageJ software.

DNA comet assay in alkaline conditions. Human leukemia HL-60 cells were treated for $24 \mathrm{~h}$ with compounds 1, 2, and Dox (all at $0.09 \mu \mathrm{M}$ ) and human leukemia K562 cells with compounds 1, 2 (both at $3 \mu \mathrm{M}$ ), and Dox $(10 \mu \mathrm{M})$ for $24 \mathrm{~h} .100 \mu \mathrm{l}$ of treated cells $(n=25,000)$ were mixed with $100 \mu$ of $0.5 \%$ low melting agarose (Promega, Madison, Wisconsin, USA) and transferred to microscopic slides covered with $1 \%$ normal molten agarose (Lachema, Brno, Czech Republic). Cells were lysed for 4-6 h at $4{ }^{\circ} \mathrm{C}$ in a buffer $(2.5 \mathrm{M} \mathrm{NaCl} ; 100 \mathrm{mM}$ EDTA; $10 \mathrm{mM}$ Tris, $\mathrm{pH}$ 10.0; 10\% DMSO, 1\% Triton X-100). Electrophoresis was performed at $25 \mathrm{~V}$ for $25 \mathrm{~min}$ in a buffer (1 mM EDTA; $300 \mathrm{mM} \mathrm{NaOH}, \mathrm{pH}$ 13.0) at $4{ }^{\circ} \mathrm{C}$. Slides were stained with ethidium bromide (EtBr, $10 \mu \mathrm{g} / \mathrm{ml}$, Sigma Aldrich, St. Louis, Missouri, USA), and visualization was performed under a Zeiss fluorescent microscope with AxioImager A1 camera (Carl Zeiss, Birkerod, Germany) and AxioVision image analysis software Release 4.6.3.0 for Carl Zeis microscopy (Imaging Associates Ltd., Cork, Ireland). For calculation of the olive tail mo- 
ment (OTL), Casplab-1.2.3b2 software (CASPLab, Wroclaw, Poland) was used. OTL was studied as a product of the detectable DNA in the comet tail, and distance between centers of the head mass and tail region, and calculated as OTL $=($ Tail mean - Head mean) $\times \%$ of tail DNA $[9,10]$.

Diphenylamine assay of DNA fragmentation. For quantitative determination of DNA fragmentation, the diphenylamine assay was used. Diphenylamine interacts with deoxyribose and results in an increase of blue colored product. Human leukemia HL-60 cells were treated for $24 \mathrm{~h}$ with compounds $\mathbf{1}$, 2, and Dox (both at $0.1 \mu \mathrm{M}$ ). K562 cells were treated with compounds $\mathbf{1}, 2$ (both at $3 \mu \mathrm{M}$ ), and Dox $(10 \mu \mathrm{M})$. Cells were lysed in $0.5 \mathrm{ml}$ Tris-EDTA buffer, $\mathrm{pH}$ 7.4, supplied with $0.2 \%$ Triton X-100 and centrifuged for $10 \mathrm{~min}$ at $12,000 \mathrm{~g}$ at $4{ }^{\circ} \mathrm{C}$. The fragmented DNA (labelled as A) was separated in a tube from intact chromatin. Supernatant that contained fragmented DNA (labelled as B) was transferred into a new tube. $0.5 \mathrm{ml}$ of $25 \%$ trichloroacetic acid (Sfera Sim, Lviv, Ukraine) was added to tubes A and B, mixed and incubated for $1 \mathrm{~h}$ at $56^{\circ} \mathrm{C}$. DNA samples were centrifuged for $10 \mathrm{~min}$ at $14,000 \mathrm{~g}$ at $4{ }^{\circ} \mathrm{C} .1 \mathrm{ml}$ of freshly prepared diphenylamine reagent $(150 \mathrm{mg}$ diphenylamine (Sigma Aldrich, St. Louis, Missouri, USA) $10 \mathrm{ml}$ glacial acetic acid, $150 \mathrm{ml}$ concentrated $\mathrm{H}_{2} \mathrm{SO}_{4}$ and $50 \mathrm{ml}$ of acetaldehyde solution) was added to pellets $\mathrm{A}$ and $\mathrm{B}$ and incubated overnight at $37^{\circ} \mathrm{C}$. Afterwards, $200 \mathrm{ml}$ of the colored solution was transferred to a 96-well plate. The optical density (OD) was measured at $630 \mathrm{~nm}$ using Absorbance Reader BioTek ELx800 (BioTek Instruments, Inc., Winooski, Vermont, USA). The percentage of DNA fragmentation was calculated as $\{\mathrm{OD}$ tube $\mathrm{B} /(\mathrm{OD}$ tube A + OD tube B) $\times 100 \%$ [ [11].

Gel retardation assay of plasmid DNA. Plasmid DNA $(1 \mu \mathrm{g} / \mu \mathrm{l}) \mathrm{pEGFPc}-1$ (Clontech, Mountain View, California, USA) was mixed with $2 \mu \mathrm{l}$ of compounds 1, $2(0.09,1.0,10.0 \mu \mathrm{M})$, and Dox $(0.09 \mu \mathrm{M})$ in $18 \mu \mathrm{l}$ of $0.9 \%$ sodium chloride (Arterium, Lviv, Ukraine) at room temperature for $1 \mathrm{~h}$. The prepared mixture was analyzed by electrophoresis in 1\% agarose gel (Lachema, Brno, Czech Republic) with $1 \times$ Tris acetate (TAE) buffer containing $1 \mu \mathrm{g} / \mathrm{ml}$ of EtBr (Sigma-Aldrich, St. Louis, Missouri, USA) for $1 \mathrm{~h}$ at a constant voltage of $70 \mathrm{~V}$. A trans-illuminator (MacroVue UV-20, Hoeffer Pharmacia Biotech Inc., San Francisco, California, USA) was used for visualization of plasmid DNA [10].
DNA intercalation assay based on using methyl green. Methyl green binds to DNA with an absorption maximum at $642 \mathrm{~nm}$. Free methyl green does not show absorption at this wavelength. Compounds that bind/intercalate with DNA replace methyl green from the methyl green-DNA complex and decrease the OD at $642 \mathrm{~nm} .485 \mu \mathrm{l}$ of salmon sperm DNA (50 $\mu \mathrm{g} / \mathrm{ml}$, Sigma-Aldrich, St. Louis, Missouri, USA) were incubated for $1 \mathrm{~h}$ at $37^{\circ} \mathrm{C}$ with $15 \mu \mathrm{l}$ of methyl green (Sigma-Aldrich, St. Louis, Missouri, USA) solution $\left(1 \mathrm{mg} / \mathrm{ml}\right.$ in $\left.\mathrm{H}_{2} \mathrm{O}\right) .500 \mu$ of compounds $\mathbf{1}, 2$ (1 and $10 \mu \mathrm{M})$, or Dox $(1,10 \mu \mathrm{M})$ were added to the methyl green-DNA complex and incubated for $2 \mathrm{~h}$ at $37^{\circ} \mathrm{C}$ in the dark. EtBr $(1$ and $10 \mu \mathrm{g} / \mathrm{ml})$ was used as a positive control. Absorption of methyl green was measured at $630 \mathrm{~nm}$ [12] using a fluorescence plate reader (Absorbance Reader BioTek ELx800, BioTek Instruments, Inc., Winooski, Vermont, USA).

Statistical analysis. The results were analyzed and illustrated with GraphPad Prism (version 6; GraphPad Software, La Jolla, California, USA), and presented as a mean \pm standard deviation. For analysis of statistical data, ANOVA test (by Dunnett's test) was used. $P$-value of $<0.05$ was considered to be statistically significant.

\section{Results and Discussion}

In a previous study [7], we demonstrated that compounds $\mathbf{1}$ and $\mathbf{2}$ possess high cytotoxicity towards human leukemia HL-60 ( IC $_{50}$ equal to $0.09 \mu \mathrm{M}$ and $0.096 \mu \mathrm{M}$, respectively) and $\mathrm{K} 562\left(\mathrm{IC}_{50}\right.$ equal to $3.0 \mu \mathrm{M}$ and $3.1 \mu \mathrm{M}$, respectively) cell lines. The acute promyelocytic leukemia HL-60 cells and chronic myeloid leukemia K562 cells are good in vitro model systems for studying cellular and molecular events involved in proliferation and differentiation of leukemic cells. Since the antineoplastic agents that selectively induce apoptotic pathways of tumor cells are of great interest for anticancer therapy strategy, in this study, we investigated the pro-apoptotic action of compounds $\mathbf{1}$ and $\mathbf{2}$.

The results of Western-blot analysis of proteins from treated human leukemia HL-60 and K562 cells are presented in Fig. 1 and 2. We detected cleavage of caspase 3 and PARP1 under the action of the studied compounds. The effector caspase 3 plays a pivotal role in apoptotic cell death [13], while PARP1 is involved in DNA repair. Besides, PARP is a substrate for caspase cleavage and, thus, can be a participant in the caspase-dependent pathway of apoptosis [13]. 
Thus, the cleavage of caspase-3 and PARP plays an essential role in the DNA damage of target cells.

Treatment of HL-60 cells with the compounds $\mathbf{1}$ and $\mathbf{2}$ also led to the up-regulation of Bim and EndoG together with a down-regulation of $\mathrm{Bcl}-2$ proteins (Fig. 1). The members of the $\mathrm{Bcl}-2$ family are the main regulators of apoptosis due to their ability to activate caspases and release cytochrome $c$ from mitochondria [4]. In complex with cytochrome $c$ and the pro-apoptotic protein APAF1, caspase 9 forms a cell destructive machine called the apoptosome. EndoG, a cell death-related endonuclease $\mathrm{G}$, is released from the mitochondria during apoptosis and causes DNA fragmentation in the nucleus [14]. The compounds 1 and $\mathbf{2}$ did not change the amount of the phosphorylated form of ERK1/2 kinase in the treated HL-60 cells (Fig. 1), however, they decreased the amount of the phosphorylated form of this enzyme in K562 cells (Fig. 2). Downregulation of ERK could be crucial for the anti-proliferative effect of anticancer agents, as well as for their anti-metastatic and anti-angiogenic properties in tumor cells [15]. We suggest that heterogeneity of these leukemia cells could be one of the reasons for the detected difference between them in ERK phosphorylation. HL-60 cells are represented mostly by the granulocyte/monocyte/macrophage lineage and approximately $10 \%$ of these cells differentiate spontaneously [16], while K562 cells are not a B-cell line and not lymphoid, rather they have a low level of differentiation and are a granulocytic type of cell [17]. K562 cells have been reported as particularly resistant to the action of apoptosis-inducing agents [18].

The effect of Dox on the level of apoptosis-related proteins in human leukemia HL-60 and K562 cells was similar to the above described effects of compound 1 and 2 (Fig. 1, 2).

Thus, the results of Western-blot analysis demonstrated that compounds $\mathbf{1}$ and $\mathbf{2}$ induce apoptosis in human leukemia HL-60 and K562 cells. The cytotoxic action of other thiazole derivatives, such as 4-(3-acetyl-5-oxo-6-phenyl-8-(thiophen-2-yl) pyrido[2,3-d] [1,2,4]triazolo[4,3-a] pyrimidin-1(5H)yl)benzenesulfonamide, (e)-4-(2,4-dichlorophenyl)2-\{2-[4-(trifluoromethyl) benzylidene]hydrazinyl\} thiazole and 5-(benzylthio)-N-phenyl-7-(p-tolylthio) thiazolo[5,4-d]pyrimidin-2-amine is related to upregulation of caspase $3 / 3$, Bax and down-regulation of Bcl-2 [1, 4, 19]. The 7-methoxy-2-oxo-2H-chromene3-carboxylic acid [4-(4-methoxy-phenyl)-thiazol- 2-yl]-amide cleaved caspase-8, caspase-3, PARP, and affected caspase activated DNase, and $\mathrm{H} 2 \mathrm{~A}$ histone family member $\mathrm{X}(\gamma-\mathrm{H} 2 \mathrm{AX})$ in murine ascitic carcinoma cells [20]. Since the studied compounds in the leukemia cells increased the level of the mitochondrial pro-apoptotic proteins Bim protein (induces Bax/Bak oligomerization on mitochondria [4]) and EndoG (nuclease that specifically degrades the DNA), and decreased the level of the mitochondrial anti-apoptotic Bcl-2 protein, we suggest a mitochondria-dependent action of these compounds. Their capability for activating caspase 3 , which is a proteinase degrading intracellular regulatory proteins including PARP1 (DNA repair enzyme), together with the above noted elevation of the EndoG nuclease could be responsible for degradation of chromosomal DNA (DNA single-strand breaks and DNA fragmentation in the leukemia cells).

DNA damage induced by the derivatives of thiazole. DNA fragmentation is a characteristic feature of apoptosis. We used an alkaline comet assay in order to identify single-strand DNA breaks and alkali-labile base damage in human leukemia HL-60 and K562 cells from their treatment with compounds $\mathbf{1}, \mathbf{2}$, and Dox. The OTL was checked as a parameter for analysis of the DNA damage. Compounds 1 and $\mathbf{2}$ induced DNA damage in HL-60 cells with the OTL $=11.0 \pm 5.8 \%$ for compound 1 and OTL $=14.9 \pm 7.7 \%$ for compound 2 (Fig. 3, C, D and Fig. 4); and in K562 cells with the OTL $=10.5 \pm 4.0 \%$ for compound 1 and $\mathrm{OTL}=10.1 \pm 7.2$ for compound 2 (Fig. 3, $G, H$ and Fig. 4). Some DNA damage was detected in control (untreated) cells (OTL $=2.4 \pm 1.1 \%$ in HL-60 cells and OTL $=1.7 \pm 0.7 \%$ in K562 cells). Dox caused more significant DNA damage in the leukemia cells $(\mathrm{OTL}=31.4 \pm 7.9 \%$ in HL-60 cells and OTL $=24.3 \pm 11.9 \%$ in K562 cells; Fig. 3, B, F and Fig. 4).

A colorimetric diphenylamine assay was used in order to define the amount of DNA fragmentation from treatment with compounds 1, 2, and Dox. An increase in the absorbance at $630 \mathrm{~nm}$ corresponded to an elevation in the amount of the apoptotic DNA fragments. The level of DNA fragmentation from Dox treatment was higher than from treatment with compounds $\mathbf{1}$ and $\mathbf{2}$. The level of fragmented DNA in HL-60 cells reached 3.8\% and 3.3\% from the action of compounds 1 and 2, respectively, and 7.9\% from the action of Dox (Fig. 5). The level of fragmented DNA in K562 cells was 7.1\% and 9.6\% from the ef- 
$A$

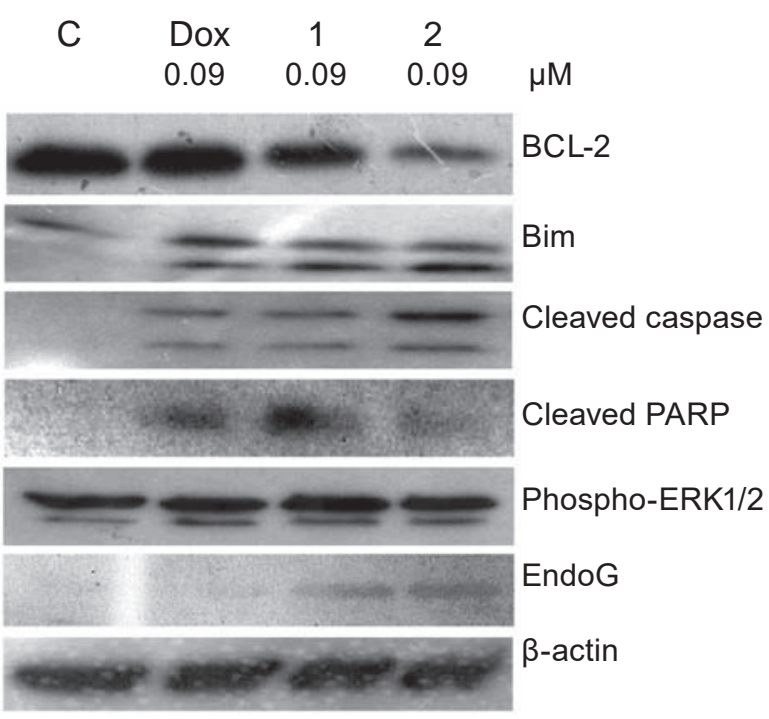

$B$
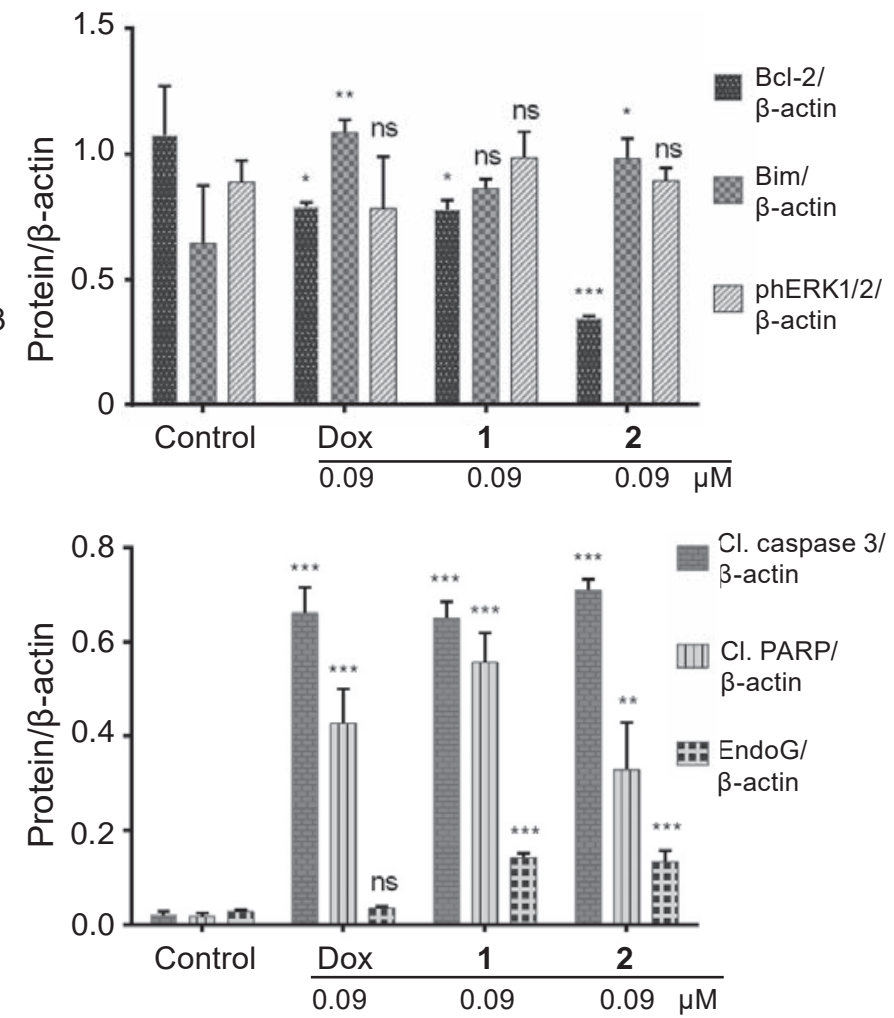

Fig. 1. The effect of compounds 1, 2, and doxorubicin (Dox) on the level of apoptosis-initiating proteins in human leukemia HL-60 cells: $\boldsymbol{A}$ - Western-blot analysis of proteins; $\boldsymbol{B}$ - densitometry of protein amount. Cells were treated for $48 \mathrm{~h}$ with compounds 1,2 and Dox. ${ }^{*} P \leq 0.05 ;{ }^{* *} P \leq 0.01, * * * P \leq 0.001$, ns-non-significant changes (difference compared with the non-treated control cells). $\mathrm{C}$-control (untreated) cells; $\mathrm{Cl}$-cleaved; EndoG-endonuclease G; ERK-extracellular signal-regulated kinase; PARP-poly (ADP-ribose) polymerase; ph-phosphorylated

fects of compounds $\mathbf{1}$ and 2, respectively, and was $33.9 \%$ from the effect of Dox (Fig. 4). Similar effects were reported for the (E)-4-(2,4-dichlorophenyl)2-\{2-[4-(trifluoromethyl)benzylidene] hydrazinyl\} thiazole on DNA fragmentation: $19.7-22.4 \%$ after treatment with this compound at a concentration of 17-34 $\mu \mathrm{M}[1]$.

Study of binding of the thiazole derivatives to DNA. The intercalation or binding of nuclear DNA is one of the mechanisms of the antineoplastic action of specific anticancer drugs (e.g. anthracyclines, 5-fluorouracil, mesalamine, cisplatin) [12, 21]. Binding with DNA blocks DNA replication, thus enhancing an efficiency of drug action [21,22].

Dox, used as a positive control, at $0.09 \mu \mathrm{M}$ inhibited the electrophoretic mobility of plasmid DNA in the agarose gel (Fig. 6, lane 2). This DNA was not retarded by compounds 1 and 2 used at 0.09, 1 and $10 \mu \mathrm{M}$ doses (Fig. 6, lanes 3-8).
Compound 1 used at 1 and $10 \mu \mathrm{M}$ concentrations slightly replaced the methyl green in a DNAmethyl green complex $(1.9 \pm 0.2 \%$ and $2.4 \pm 0.3 \%$, respectively, Fig. 7). Compound 2 used at 1 and $10 \mu \mathrm{M}$ doses showed a similar ability for methyl green replacement $(1.6 \pm 0.1 \%$ and $1.7 \pm 0.2 \%$, respectively, Fig. 7). While Dox at 1 and $10 \mu \mathrm{M}$ doses totally replaced the methyl green $(94.1 \pm 10.1 \%$ and $105.8 \pm 13.7 \%$, respectively). EtBr (1 and $10 \mu \mathrm{g} / \mathrm{ml})$, a well-known intercalating agent, was used as a positive control and demonstrated $74.8 \pm 10.1 \%$ and $96.5 \pm 13.71 \%$ of methyl green replacement, respectively.

A capability of binding to calf thymus DNA was reported for different thiazole derivatives (pyrazolo[3,4-d]pyrimidine-benzimidazoles) [23], as well as for iminoacylated 2-amino pyridylthiazole derivatives and copper-containing thiazolepyridine compounds [24]. Molecular docking and 
$A$

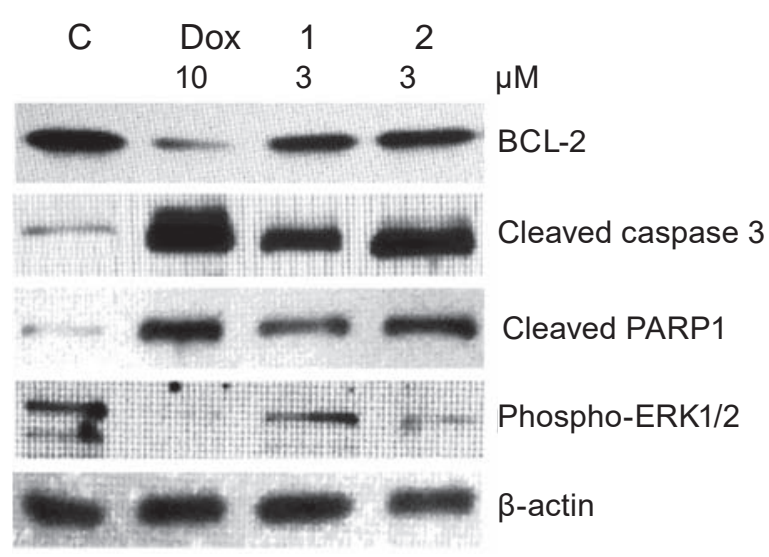

$B$
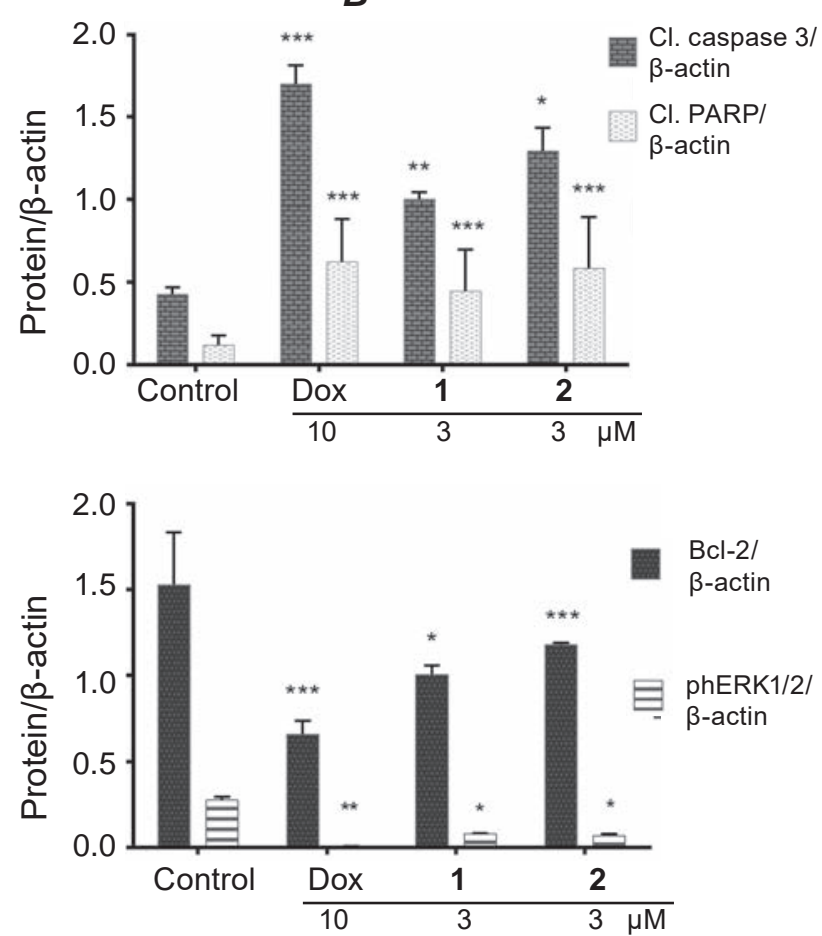

Fig. 2. The effect of compounds 1, 2, and doxorubicin (Dox) on the level of apoptosis-initiating proteins in human leukemia K562 cells: $\boldsymbol{A}$ - Western-blot analysis of proteins; $\boldsymbol{B}$ - densitometry of protein amount. ${ }^{*} P \leq 0.05 ;{ }^{* *} P \leq 0.01 ; * * * P \leq 0.001$. $C$ - control (untreated) cells; $C l$ - cleaved; ERK-extracellular signalregulated kinase; $P A R P$ - poly (ADP-ribose) polymerase; $p h$ - phosphorylated

fluorescent spectroscopy (EtBr replacement) approaches were applied to confirm binding of studied compounds to the DNA molecule [23, 24]. We have used the electrophoretic retardation of plasmid DNA and replacement of methyl green dye for confirmation of our suggestion that compounds $\mathbf{1}$ and 2 neither bind DNA directly nor intercalate into the DNA molecule. Earlier, it was demonstrated that an anticancer alkaloid (chelidonine) does not bind DNA, however, it induced apoptosis with delayed (12-24 h) DNA damage revealed by the DNA comet assay and DNA laddering analysis [25]. In that study, it was suggested that such DNA damage was a result of secondary events in the apoptosis pathway, since the related alkaloids (sanguinarine and chelerythrine) which definitely intercalated salmon sperm DNA caused DNA damage much earlier (1-3 h) [25]. There is another potential mechanism by which the cytotoxic agents (anticancer drugs) can damage the DNA even without a direct interaction with its molecule. Recently, we have detected that N-(5-benzyl-1,3thiazol-2-yl)-3,5-dimethyl-1-benzofuran-2-carboxamide derivative did not bind the DNA, however, it induced hydrogen peroxide (i.e., reactive oxygen species [ROS]) accumulation and DNA fragmentation (DNA comet assay in alkaline conditions) in human glioblastoma U251 and T98G cells [10]. The ROS-induced death of tumor cells was associated with the down-regulation of PARP1 (DNA repair enzyme) and mitochondrial depolarization (indicator of apoptosis) [26]. Thus, we suggest that compounds $\mathbf{1}$ and $\mathbf{2}$ induced apoptosis in the studied leukemia cells via mechanisms that are not directly dependent on DNA binding or intercalation.

Summarizing, the anti-proliferative action of the studied compounds $\mathbf{1}$ and $\mathbf{2}$ is associated with apoptosis induction via a mitochondria-dependent mechanism. Particularly, these compounds increased the level of the pro-apoptotic Bim protein and decreased the level of the anti-apoptotic Bcl-2 protein, as well as increased the level of the mitochondrionspecific EndoG nuclease, and also activated caspase 3 and caused cleavage of PARP1. Besides, these compounds caused DNA single-strand breaks and DNA fragmentation in human leukemia cells without significant DNA binding or DNA intercalation. Thus, the 2-amino-5-benzylthiazole derivatives may be promising agents for killing human leukemia 


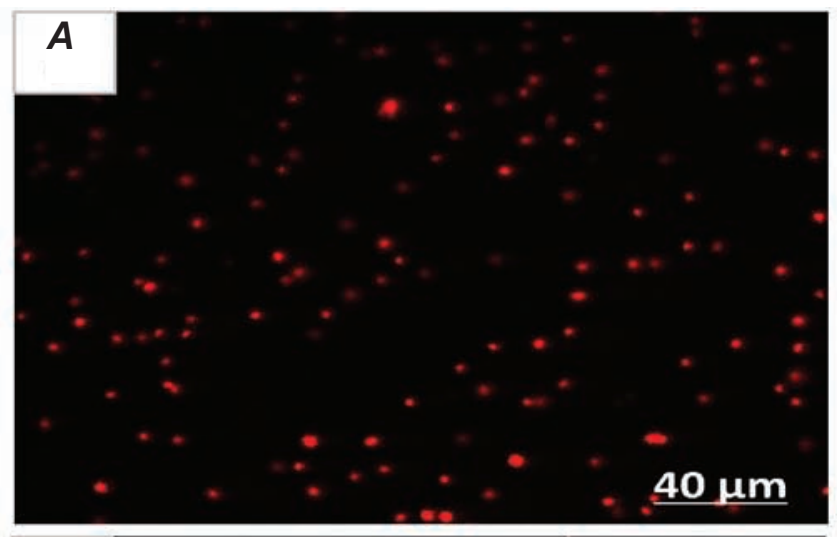

\section{B}
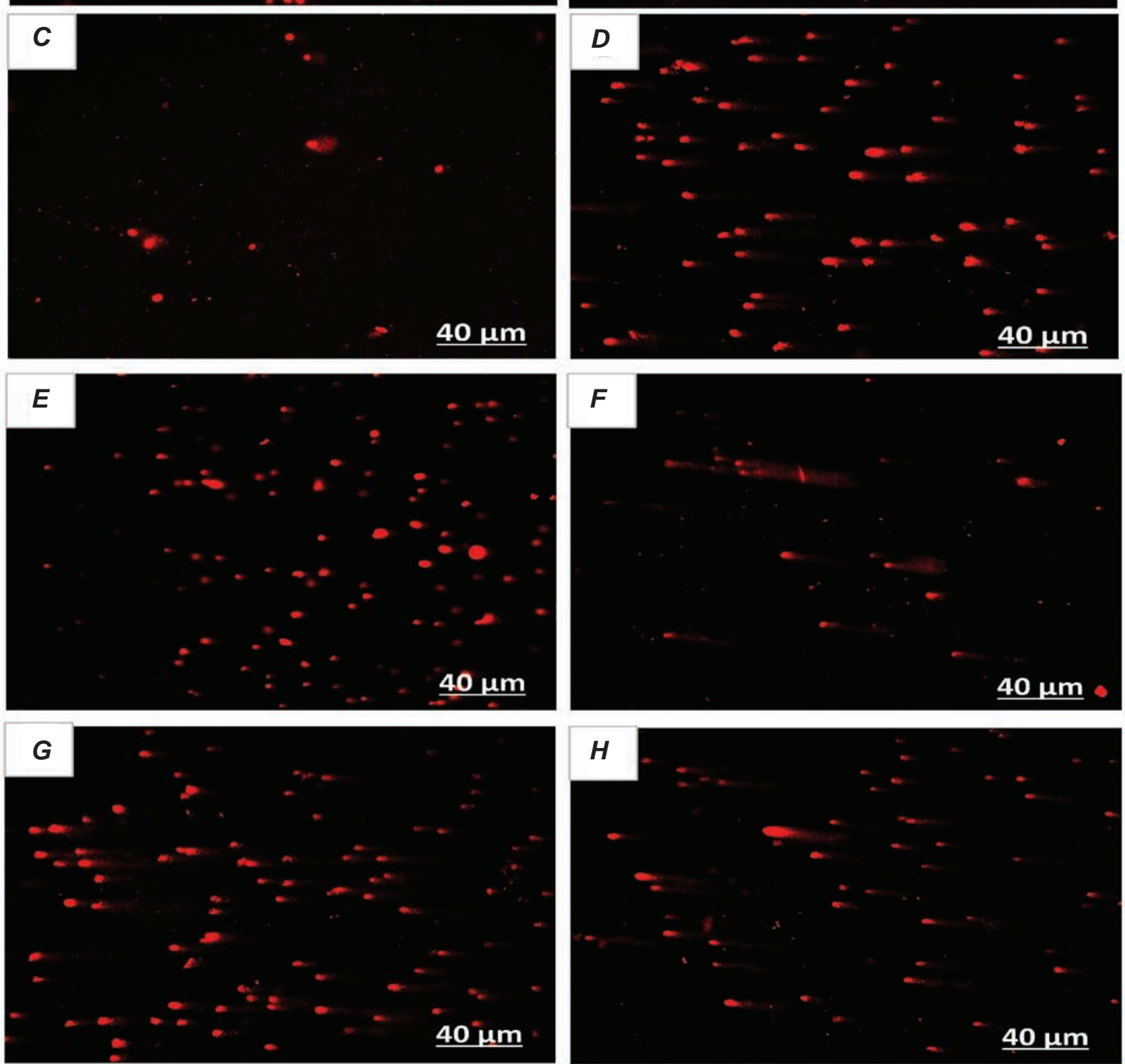

\section{$H$}

$40 \mu \mathrm{m}$

Fig. 3. The DNA damage from compounds 1, 2, and doxorubicin (Dox) in human leukemia HL-60 cells (Acontrol; B - Dox, $0.09 \mu \mathrm{M} ; \boldsymbol{C}$ - compound 1, $0.09 \mu \mathrm{M} ; \mathbf{D}$ - compound 2, $0.09 \mu \mathrm{M})$ and K562 cells (E-control; $\boldsymbol{F}-$ Dox, $10 \mu \mathrm{M} ; \boldsymbol{G}$ - compound 1, $3 \mu \mathrm{M} ; \boldsymbol{H}$ - compound 2, $3 \mu \mathrm{M}$ ) 

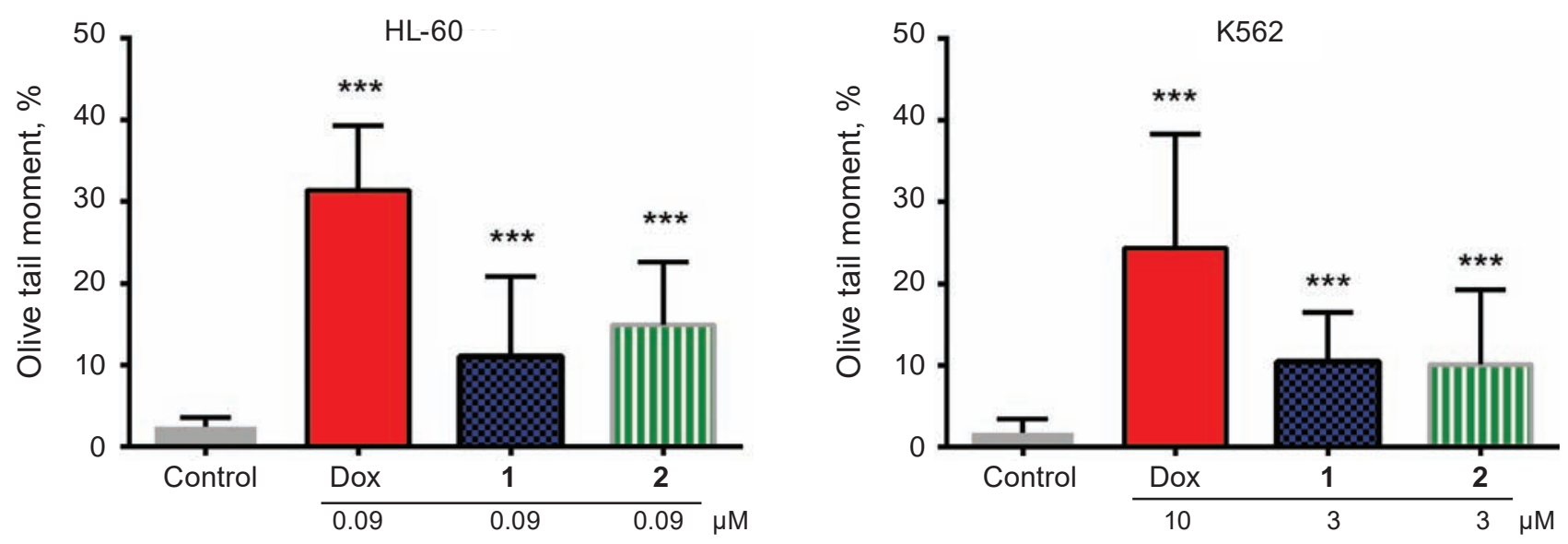

Fig. 4. The quantitative data of DNA damage (Olive Tail Moment) from compounds 1, 2, and doxorubicin (Dox) human leukemia HL-60 and K562 cells. ${ }^{* * * P}<0.001$ (significant changes compared with control (untreated) cells)
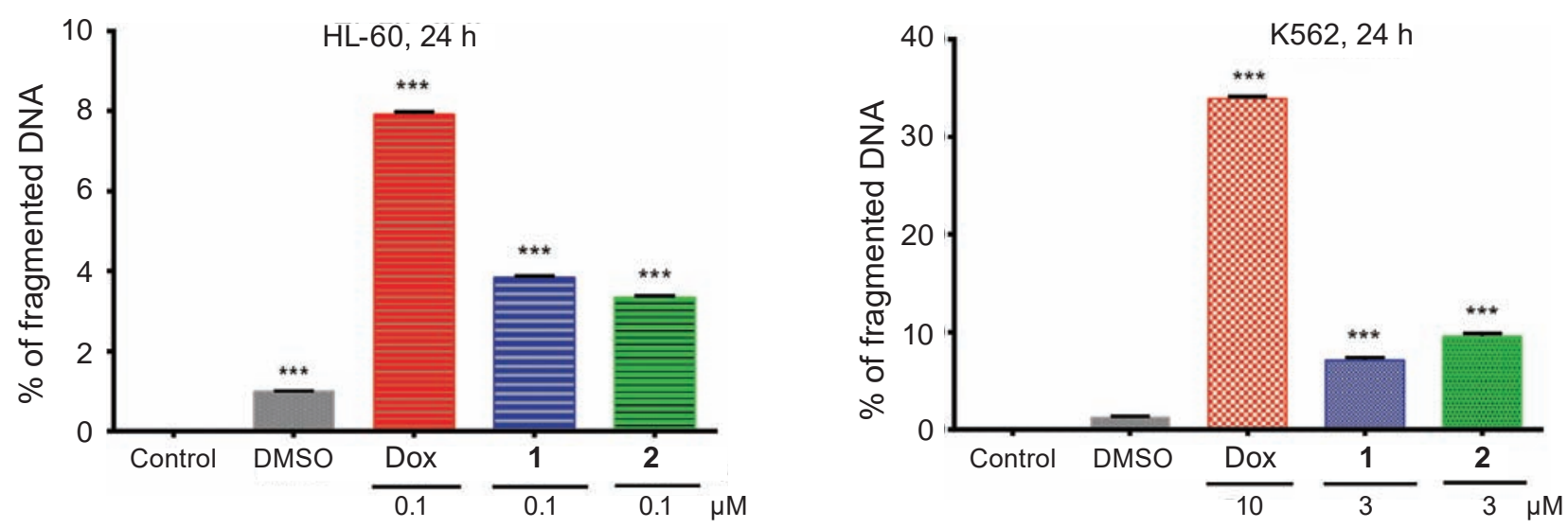

Fig. 5. The level of DNA fragmentation caused by compounds 1, 2, and doxorubicin (Dox) in human leukemia HL-60 and K562 cells. The diphenylamine method was used for quantitative identification of DNA fragmentation. ${ }^{* * * P}<0.001$ (significant changes compared with control (untreated) cells). DMSO-dimethyl sulfoxide

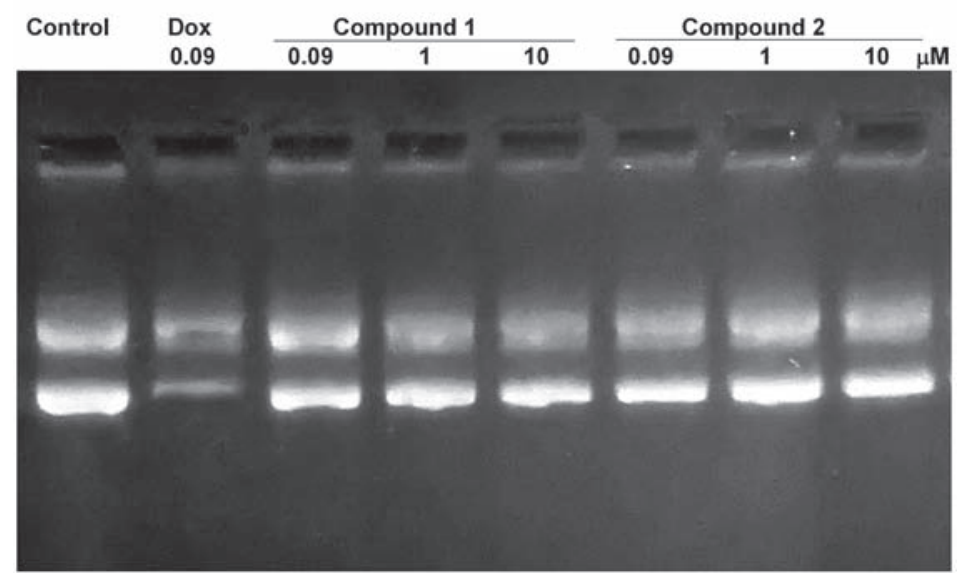

Fig. 6. The results of electrophoretic retardation of plasmid DNA ( $p D N A)$ by doxorubicin (Dox) and compounds 1 and 2: lane 1 control (native) pDNA pEGFP c-1; 2 - Dox, $0.09 \mu M+p D N A ; 3$ - compound 1, $0.09 \mu M$ + pDNA; 4-compound 1, $1 \mu M+p D N A ; 5-$ compound 1, $10 \mu M+p D N A ; 6$ - compound 2, $0.09 \mu M+$ pDNA; 7 - compound 2, $1 \mu M+$ $p D N A ; 8$ - compound 2, $10 \mu M+p D N A$. The studied compounds were added to a sample of $p D N A$ $p E G F P c-1$, the mixture was kept for $1 \mathrm{~h}$ at room temperature, and then subjected to electrophoresis in the agarose gel 


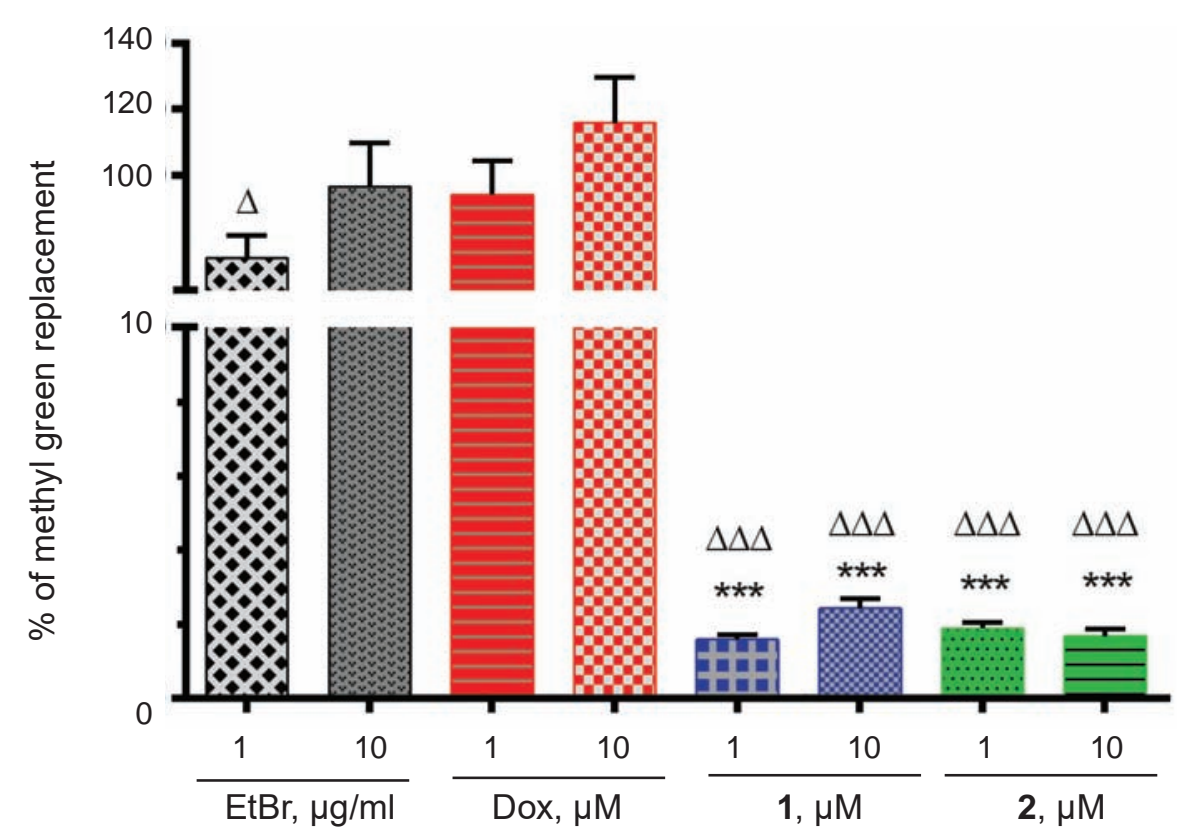

Fig. 7. The results of measuring replacement of methyl green from a DNA-methyl green complex by compounds 1, 2 and doxorubicin (Dox) and ethidium bromide (EtBr, positive control). *** $P<0.001$ (significant changes compared with EtBr $(10 \mu \mathrm{g} / \mathrm{ml})$ effect); $\Delta P<0.05$ (significant changes compared with Dox $(10 \mu M)$ effect); $\Delta \Delta \Delta P<0.001$ (significant changes compared with Dox $(10 \mu M)$ effect)

cells. Further studies of the mechanism of cytotoxic action of 2-amino-5-benzylthiazole derivatives using flow cytometry for evaluation of cell cycling, production of ROS, and flow cytometry, fluorescence microscopy examinations of mitochondria transmembrane potential, as well as studies of the effects of these derivatives in tumor-bearing mice are in progress.
Conflicts of interest. The authors declare no conflict of interest.

Acknowledgements. This study was supported by the Ministry of Education and Science of Ukraine grant (registration number 0116U001533, 2016-2018 PI Dr. Andriy Babsky). 


\section{ІНДУКЦІЯ АПОПТОЗУ У ЛЕЙКОЗНИХ КЛІТИНАХ ЛЮДИНИ ЗА ДІї НОВИХ ПОХІДНИХ 2-АМІНО-5-БЕНЗИЛТІАЗОЛУ}

\author{
Н. С. Фінюк ${ }^{1,2}$, I. I. Івасечко ${ }^{1}$, \\ О. Ю. Ключівська ${ }^{1}$, Ю. В. Остап'юк ${ }^{3}$, \\ В. П. Гренюх², Я. Р. Шалай², \\ В. С. Матійчук ${ }^{3}$ М. Д. Обушак ${ }^{3}$, \\ A. М. Бабськийㄹ, Р. С. Стойка
}
${ }^{1}$ Інститут біології клітини НАН України, Львів; ${ }^{2}$ Львівський національний університет імені Івана Франка, біологічний факультет, Україна; $3^{3}$ Јьівський національний університет імені Івана Франка, хімічний факультет, Україна; 凶e-mail: stoika@cellbiol.lviv.ua

Похідні 2-аміно-5-бензилтіазолу $\epsilon$ гетероциклічними сполуками, які виявляють різноманітні фармакологічні властивості, в тому числі протипухлинну дію, механізми якої ще недостатньо вивчені. Метою цього дослідження було з'ясування дії двох новосинтезованих похідних тіазолу - 2,8-диметил-7-(3трифторметил-бензил)піразоло[4,3-е]тіазоло[3,2-а]піримідин-4 (2Н)-он (сполука 1) і 7-бензил8-метил-2-пропілпіразоло[4,3-е] тіазоло[3,2-а]піримідин-4(2Н)-он (сполука 2) - на індукцію апоптозу та структуру ДНК у лейкозних клітинах людини. У цій роботі застосовували Вестернблот аналіз, ДНК-комет аналіз в лужних умовах, дифеніламіновий метод, ДНК-електрофорез в агарозному гелі, аналіз інтеркаляції ДНК із застосуванням метилового зеленого для вивчення впливу досліджуваних сполук на клітини лейкозу. Встановлено, що ці сполуки активують розщеплення PARP1 і каспази 3, а також збільшення рівня проапоптотичного протеїну Bim та специфічної мітохондріальної нуклеази EndoG, i зниження рівня антиапоптичного протеїну Bcl2. Дія цих речовин призводить до одноланцюгових розривів у молекулі ДНК і фрагментації ДНК у лейкозних клітинах. Проте ці сполуки не зв'язуються з ДНК і не інтеркалюють у структуру їі молекули. Отже, нові похідні 2-аміно-5бензилтіазолу є потенційними сполуками, які індукують апоптоз у лейкозних клітинах людини.

К л юч в в $\quad$ слов а: 2-аміно-5бензилтіазол, доксорубіцин, апоптоз, пошкодження ДНК, лейкоз.

\section{References}

1. de Santana TI, Barbosa MO, Gomes PATM, da Cruz ACN, da Silva TG, Leite ACL. Synthesis, anticancer activity and mechanism of action of new thiazole derivatives. Eur J Med Chem. 2018; 144: 874-886.

2. Ismail NSM, Ali EMH, Ibrahim DA, Serya RAT, Abou El Ella DA. Pyrazolo[3,4-d]pyrimidine based scaffold derivatives targeting kinases as anticancer agents. Future J Pharmac Sci. 2016; 2(1): 20-30.

3. Sunil D, Isloor AM, Shetty P, Satyamoorthy K, Bharath Prasad AS. 6-[3-(4-Fluorophenyl)-1Hpyrazol-4-yl]-3-[(2-naphthyloxy)methyl][1,2,4] triazolo[3,4-b][1,3,4]- thiadiazole as a potent antioxidant and an anticancer agent induces growth inhibition followed by apoptosis in HepG2 cells. Arabian J. Chem. 2010; 3(4): 211217.

4. Li ZH, Zhang J, Liu XQ, Geng PF, Ma JL, Wang B, Zhao TQ, Zhao B, Wei HM, Wang C, Fu DJ, $\mathrm{Yu}$ B, Liu HM. Identification of thiazolo[5,4-d] pyrimidine derivatives as potent antiproliferative agents through the drug repurposing strategy. Eur J Med Chem. 2017; 135: 204-212.

5. Dos Santos TA, da Silva AC, Silva EB, Gomes PA, Espíndola JW, Cardoso MV, Moreira DR, Leite AC, Pereira VR. Antitumor and immunomodulatory activities of thiosemicarbazones and 1,3-Thiazoles in Jurkat and HT-29 cells. Biomed Pharmacother. 2016; 82: 555-560.

6. Song XJ, Shao Y, Dong XG. Microwaveassisted synthesis of some novel fluorinated pyrazolo[3,4-d]pyrimidine derivatives containing 1,3,4-thiadiazole as potential antitumor agents. Chin Chem Lett. 2011; 22(9): 1036-1038.

7. Finiuk NS, Ostapiuk YuV, Hreniukh VP, Shalai Ya R, Matiychuk VS, Obushak MD, Stoika RS, Babsky AM. Evaluation of antiproliferative activity of pyrazolothiazolopyrimidine derivatives. Ukr Biochem J. 2018; 90(2): 25-32.

8. Senkiv J, Finiuk N, Kaminskyy D, Havrylyuk D, Wojtyra M, Kril I, Gzella A, Stoika R, Lesyk R. 5-Ene-4-thiazolidinones induce apoptosis in mammalian leukemia cells. Eur J Med Chem. 2016; 117: 33-46.

9. Liao W, McNutt MA, Zhu WG. The comet assay: a sensitive method for detecting DNA damage in individual cells. Methods. 2009; 48(1): 46-53. 
10. Finiuk N, Klyuchivska O, Ivasechko I, Hreniukh V, Ostapiuk Y, Shalai Y, Panchuk R, Matiychuk V, Obushak M, Stoika R, Babsky A. Proapoptotic effects of novel thiazole derivative on human glioma cells. Anticancer Drugs. 2019; 30(1): 27-37.

11. Arora S, Tandon S. DNA fragmentation and cell cycle arrest: a hallmark of apoptosis induced by Ruta graveolens in human colon cancer cells. Homeopathy. 2015; 104(1): 36-47.

12. Filak LK, Mühlgassner $G$, Jakupec MA, Heffeter P, Berger W, Arion VB, Keppler BK. Organometallic indolo[3,2-c]quinolines versus indolo[3,2-d]benzazepines: synthesis, structural and spectroscopic characterization, and biological efficacy. J Biol Inorg Chem. 2010; 15(6): 903-918.

13. Davar D, Beumer JH, Hamieh L, Tawbi H. Role of PARP inhibitors in cancer biology and therapy. Curr Med Chem. 2012; 19(23): 3907-3921.

14. Zhdanov DD, Fahmi T, Wang X, Apostolov EO, Sokolov NN, Javadov S, Basnakian AG. Regulation of Apoptotic Endonucleases by EndoG. DNA Cell Biol. 2015; 34(5): 316-326.

15. Kohno M, Pouyssegur J. Targeting the ERK signaling pathway in cancer therapy. Ann Med. 2006; 38(3): 200-211.

16. Birnie GD. The HL60 cell line: a model system for studying human myeloid cell differentiation. Br J Cancer Suppl. 1988; 9: 41-45.

17. Klein E, Ben-Bassat H, Neumann H, Ralph P, Zeuthen J, Polliack A, Vánky F. Properties of the K562 cell line, derived from a patient with chronic myeloid leukemia. Int J Cancer. 1976; 18(4): 421-431.

18. Luchetti F, Gregorini A, Papa S, Burattini S, Canonico B, Valentini M, Falcieri E. The K562 chronic myeloid leukemia cell line undergoes apoptosis in response to interferon-alpha. Haematologica. 1998; 83(11): 974-980.

19. Nitulescu GM, Draghici C, Olaru OT, Matei L, Ioana A, Dragu LD, Bleotu C. Synthesis and apoptotic activity of new pyrazole derivatives in cancer cell lines. Bioorg Med Chem. 2015; 23(17): 5799-808.
20. Prashanth T, Vijay Avin BR, Prabhu Thirusangu, Lakshmi Ranganatha V, Prabhakar BT, Narendra Sharath Chandra JN, Shaukath Ara Khanum. Synthesis of coumarin analogs appended with quinoline and thiazole moiety and their apoptogenic role against murine ascitic carcinoma. Biomed Pharmacother. 2019; 112: 108707.

21. Shahabadi N, Fili SM, Kheirdoosh F. Study on the interaction of the drug mesalamine with calf thymus DNA using molecular docking and spectroscopic techniques. $J$ Photochem Photobiol B. 2013; 128: 20-26.

22. Palchaudhuri R, Hergenrother PJ. DNA as a target for anticancer compounds: methods to determine the mode of binding and the mechanism of action. Curr Opin Biotechnol. 2007; 18(6): 497-503.

23. Singla P, Luxami V, Singh R, Tandon V, Paul K. Novel pyrazolo[3,4-d]pyrimidine with 4-(1H-benzimidazol-2-yl)-phenylamine as broad spectrum anticancer agents: Synthesis, cell based assay, topoisomerase inhibition, DNA intercalation and bovine serum albumin studies. Eur J Med Chem. 2017; 126: 24-35.

24. Bera P, Brandao P, Mondal G, Santra A, Jana A, Mokhamatam RB, Kumar Manna S, Mandal TK, Bera P. An unusual iminoacylation of 2-amino pyridyl thiazole: Synthesis, X-ray crystallography and DFT study of copper (II) amidine complexes and their cytotoxicity, DNA binding and cleavage study. Polyhedron. 2019; 159: 436-445.

25. Kaminskyy V, Kulachkovskyy O, Stoika R. A decisive role of mitochondria in defining rate and intensity of apoptosis induction by different alkaloids. Toxicol Lett. 2008; 177(3): 168-181.

26. Zheng L, Wang C, Luo T, Lu B, Ma H, Zhou Z, Zhu D, Chi G, Ge P, Luo Y. JNK Activation Contributes to Oxidative Stress-Induced Parthanatos in Glioma Cells via Increase of Intracellular ROS Production. Mol Neurobiol. 2017; 54(5): 3492-3505. 